\title{
What is Religious Misconduct: A Typological Analysis of the Crimes Motivated by Polytheistic Religion, Using the Chinese Folk Religion as an Example
}

\author{
Hua-Lun Huang*
}

\author{
Department of Sociology, Anthropology, and Child and Family Studies at the University of Louisiana, \\ Lafayette, USA
}

\begin{abstract}
In terms of political function, religion is usually defined by criminologists/sociologists as an institution of social control. While religion can assist state managers to maintain the status quo and to safeguard social order, religion, under certain circumstances, can become an antisocial force as well. In this paper, the criminogenic side of religions will be examined. By using the Chinese folk religion as an example, this paper will demonstrate that polytheistic religions can become unstable social organizations. Four topics will be addressed in this paper. First, the research paradigms that can help crime researchers examine the subject of religious misconduct will be summarized. Then the features shared by polytheistic religions will be proposed. The third part will look at the primary traits of Chinese folk religion. Finally, by using the Chinese folk religion as an instance, the diverse contexts under which polytheistic religions can breed deviant/criminal behaviors will be analyzed.
\end{abstract}

Keywords: Crime of trust, Crime of obedience, Karma, Rebirth, Sex Crime.

\section{INTRODUCTION}

In criminology, some topics seem to be regarded by criminologists as "politically incorrect" subjects," because a systematic examination of these issues may lead to legal disputes or even political crisis. ${ }^{1}$ For that very reason, "politically sensitive" or "criminologically improper" issues usually are not considered to be "suitable topics" for crime researchers to address (e.g., inspecting these subject matters might provoke racial conflicts, trigger interclass clashes, weaken the status of mainstream churches, or even undermine the legitimacy of a political regime ${ }^{2}$ ).

In terms of sensitive or provocative nature, religion is generally defined as a variable inadequate to accounting for the root causes of conventional crimes (i.e., offenses other than hate crime and terrorist act) for the following reasons:

First, religion is a "sacrosanct social field." As a result, religion (at least in theory) is incompatible with

*Address correspondence to this author at the Department of Sociology, Anthropology, and Child and Family Studies at the University of Louisiana, Lafayette, USA; Tel: 337-482-6044; Fax: 337-482-5374;

E-mail: hxh0555@louisiana.edu

\footnotetext{
${ }^{1}$ One important factor that can make a research topic politically or criminologically "unsuitable" is that this subject involves cultural taboos, moral interdictions, religious profanity, enormous commercial benefits, or national security (especially behind-the-scenes deals). Since this subject matter is "sensitive" in nature (see Lee, 1993), criminologists (as well as other social scientists) usually are encouraged to explore "less sensitive issues" or "mainstream social problems" so that traditional social, political, or religious order will not be challenged.

${ }^{2}$ One typical example of "improper subject" in criminology is government crime, which, according to Rosoff et al. (2002: 292), includes "the use of human "guinea pigs'," "the violation of sovereignty," and "the abuse of power."
}

immorality and crime (much like water is incompatible with oil).

Given that religion is a "sacred social field," this "holy domain" will naturally operate as an institution of social control. More specifically, except for those few cases of state-mandated atheism (e.g., North Korea, where all religious beliefs are suppressed), religion is usually the only source of moral standards and behavioral boundary for the public (this quality tends to be very obvious in traditional Islamic societies). Such pro-social traits strongly imply that religion can function as a "quasi-law enforcement body" because it has the moral authority to put a label on those persons who do not behave according to traditional norms (e.g., people who practice polygamy usually are regarded as deviants/delinquents in conservative Christian societies for these polygamists do not behave according to the moral yardsticks set up by the Bible). Considering that religion has the power of making a distinction between "the normal" and "the abnormal" and can make those people who do not act in the religiously prescribed manner suffer punishments (which can range from social isolation to public execution), it is not surprising that religion can effectively assist law enforcement authorities in discouraging people from committing criminal/deviant behaviors.

In addition to helping law enforcement authorities keep criminal/deviant behaviors under control, religion (no matter whether it is monotheistic or polytheistic) can supply a "sanctuary" or a "divine social space" (e.g., Buddhist shrine, Christian church, Hindu temple, Islamic mosque, and so forth) to followers. Because of 
this social service, not only can religion provide adherents with an arena to engage in those theological discourses which can help individuals develop socially expected qualities, it also offers people a social setting where believers can find spiritual sustenance and/or emancipation (in other words, religion has, to an extent, the function of "spiritual purification").

Finally, regardless of its faith, religion is a knowledge system about unseen domain, such as invisible beings and spiritual worlds. As a result of this function, religion, by some means, can remind people that they will be punished by deities if they violate any of the codes of conduct prescribed by sacred texts (e.g., the Ten Commandments in the Bible or the law of karma advocated by Hinduism). The idea that evil individuals always will get punishments in due course then lays a foundation for social control (this may partially explain why many people routinely behave in a socially endorsed mode).

Based on the reasons listed above, it seems reasonable to declare that the great majority of extant literature on delinquency/deviance theory underestimate the weight of religion in inducing a person to commit criminal/deviant behaviors. This position is well summarized by Kurst-Swanger (2008: 142):

... criminological research has rarely considered religious groups in its matrix of structured group criminality, and religious groups have generally not been studied alongside gangs, the mafia, or other criminal enterprises.

The same viewpoint is also expressed by Hamm (1994: 197):

Unlike the drug-crime connection, the relationship between religion and criminal behavior is one of the least understood in all of criminology.

In this paper, the mainstream assumption that religion is not a suitable variable in explaining the origins of conventional offenses will be critiqued. The following four subject matters will be addressed in the subsequent sections:

First, the research approaches that can help crime researchers describe and analyze religious misconduct will be suggested and compared;

Then the core features of polytheistic religion will be summarized and categorized;
After the principal qualities of polytheistic religion are examined, the defining characteristics of Chinese folk religion will be shown and classified;

Finally, by using the Chinese folk religion as an example, the contexts under which polytheistic religion can function as criminogenic factors will be specified and contrasted.

\section{THE STUDY OF RELIGIOUSLY-INDUCED CRIME ${ }^{3}$}

As previously mentioned, when criminologists and sociologists try to identify the factors that motivate people to commit criminal/deviant behaviors, religion usually is excluded from this examination or classification. Under such conditions, students researching the subject of religious misconduct will usually find it difficult to obtain information about this issue in mainstream texts on criminology or delinquency. ${ }^{4}$

Given that the majority of criminological texts do not seem to contain information about religious misconduct (RM), this paper suggests that this type of offense can be characterized as an opportunistic crime (i.e., scrutinizing RM in the context of crime of specialized access), an organizational crime (i.e., examining RM in the context of occupational crime), or a ritualistic crime (i.e., inspecting RM in the context of occult crime). The core ideas of these alternative approaches can be concisely described as follows:

\section{RELIGIOUS MISCONDUCT AS A CRIME OF SPECIALIZED ACCESS}

According to Felson and Boba (2010: 122), a misconduct can be considered as a "crime of

\footnotetext{
${ }^{3}$ In this article, the term religious misconduct, the idea religiously-induced crime, and the phrase religion-related crime proposed by Kurst-Swanger (2008: 9 ) will be used interchangeably. All of these expressions refer to those corrupt, violent, and/or illegal behaviors inspired by the teachings of a religion (including world religion; for a list of world religions, see Cooke, 2011 and Smith, 1991) or affiliated with the institutionalized arrangements of a certain religious organization. Such misbehaviors can be invisible offenses (e.g., certain faith leaders or trusted clergies use their power to obscure child sexual abuses or to justify tax evasion/embezzlement; see Jenkins, 1996; Parkinson, 2003; Rosoff et al. 2002) or landmark events (e.g., some authoritarian/totalitarian regimes mobilize the army to wipe out those populations who practice "evil religions"). The former can be characterized by what Kurst-Swanger (2008) called clergy misconducts or crimes of the cloth (such as misappropriation of public funds, tax fraud, sexual abuse of children, and so forth; see Kurst-Swanger, 2008: 189-222; Rosoff et al., 2002: 201-207). The latter can be exemplified by the socalled "Christian Holy War" waged by the Serbian soldiers in Bosnia in the 1990s (see Sells, 1996).

${ }^{4}$ One good example that can demonstrate this condition is offered by Shoemaker's Juvenile Delinquency (2018). In this book, most chapters are about those non-religious factors that may motivate people to commit delinquent acts. In contrast, only three pages (i.e., pages 88 to 90 ) are about the relationship between religion and delinquency.
} 
specialized access" (COSA) if that misbehavior simultaneously displays the next three qualities ${ }^{5}$ :

1. Offender plays a legitimate social role;

2. Offender and his/her victim share the same activity space; and

3. Offender can legally interact with and his/her victim because of the role s/he plays.

Based on Felson and Boba's (2010) definition, religious misconduct can be seen as a COSA because of the subsequent reasons:

First, in most cases of religion-related crime, offender is a religious staff or leader (e.g., preacher, mullah, rabbi, or master; see Rosoff et al., 2002: 195209);

Since offender is normally a religious worker, this person usually plays a respected role;

Possessing a revered position then allows offender to interact with victim in a teacher-student (or seniorjunior) relationship;

After an authority figure of a religious organization and a member of that association start to interact, this interaction may increasingly become an obnoxious or sadistic contact if it repeatedly takes place in a religious sites (where religious rites are performed or religious courses/trainings are offered) and, from time to time, involved abusive behaviors ${ }^{6}$.

\section{RELIGIOUS MISCONDUCT AS AN OCCUPATIONAL CRIME}

In addition to viewing religion-related crime as a crime of specialized access, the other approach or theoretical framework that can help criminologists analyze religious misconduct is to characterize religionrelated crime as an occupational offense ${ }^{7}$.

In terms of defining characteristic, occupational crime is usually characterized by two features. First,

\footnotetext{
${ }^{5}$ Felson and Boba (2010: 119) argue that crime of specialized access is "a criminal act committed by abusing one's job or profession to gain specific access to a crime target."

${ }^{6}$ For example, in the name of "sex therapy," some Catholic fathers allegedly got involved in child molestation (see Bruni \& Burkett, 2002; Jenkins, 1996; Parkinson, 2003)

${ }^{7}$ While the two concepts of crime of specialized access and occupational crime are closely related, the former seems to focus on those crimes caused by spontaneous (or short-term) opportunity makeup. In contrast, the latter tends to focus on those delinquent acts produced by institutionalized (or long-term) opportunity structure.
}

this offense is perpetrated by people recognized as experts or skilled workers in a certain field. As a result, such crime can be disguised as a "professional act" when perpetrators are performing their routine work. This camouflage can be exemplified by many cases (see Green, 1996: 194).

Besides the attribute of disguise (i.e., criminal acts can be obscured as "professional behaviors"), the other trait of occupational crime is that it is a long-standing behavior. That is, occupational crime usually occurs within a social organization, which can be as small as an oil-changing workshop or as big as a transnational corporation. Since this organization will assign a working space (which is normally independent from public supervision) to all employees, such space provides criminals (who can be white-collar, blue-collar, or pink-collar offenders) with an opportunity structure to commit criminal or immoral behaviors. This may explain why occupational crime is typically recurrent.

For the following reasons, it seems adequate to declare that religious misconduct is a subcategory of occupational crime:

First, religion-related crime is, more often than not, committed by staff affiliated with a religious group (particularly leaders and spiritual gurus of the group). Accordingly, religious misconduct will be seen as a "professional behavior" if perpetrators are considered by the public as competent individuals in charge of religious affairs (or "masters" who can help people explore psychic ability and/or spiritual potential).

Apart from the element of concealment, religious misconduct also contains the component of continuity. That is, religion-related crime is normally perpetrated inside a religious organization (which can be as small as a religious sect led by a charismatic person or as big as a megachurch) and in the context of legitimate activities like "spiritual therapy." For that reason, corrupt religious figures are able to find occasions to commit illegal/immoral acts within a religious association if such acts are disguised behind the label of "professional behavior."

\section{RELIGIOUS MISCONDUCT AS A RITUALISTIC CRIME}

Compared to the two perspectives proposed above (i.e., viewing religious-induced crime as a crime of specialized access or occupational crime), seeing religion-related crime as a ritualistic offense is perhaps the most straightforward method in helping crime 
researchers analyze religious misconduct. This simplicity can be clearly observed from the fact that ritualistic offenses are theologically grounded crime:

Unlike the study of crime of specialized access and occupational crime, which usually involves the examination of various factors at both micro and macro levels, the research of ritualistic crime will require investigators to focus their attention on one particular aspect-- i.e., inspecting a belief system or theology considered to be heretical. The main reason for this "low research requirement" is that ritualistic crime is a belief-motivated or theologically based offense. As a result, scrutinizing the teachings of an unorthodox theology (held by deviant cults or some religious people) can promptly help researchers identify the root cause that stimulates fanatic members of religious cults (or certain "exceedingly pious persons") to get involved in murder, terrorist movement, or other crimes (see Corbiscello, 2000). This phenomenon (i.e., how a belief system of a criminal cult functions as the primary factor in motivating followers to commit ritualistic crime) can be exemplified by Reader's (2000) study of Aum Shinrikyō (a doomsday cult in Japan, which carried out the sarin attack at the Tokyo subway in 1995).

In summary, religious misconduct, to an extent, can be seen as a crime of specialized access, an occupational crime, or a ritualistic crime. None of these viewpoints or approaches, however, has evolved into a mainstream paradigm in criminology or criminal justice study in the past two decades.

The purpose of this paper is to expand extant research on religious misconduct. By using the Chinese folk religion as an example, this paper aims to examine the possible connections between polytheistic religion and crime.

\section{MAINSTREAM PARADIGMS ON THE RESEARCH OF RELIGIOUS MISCONDUCT}

As indicated above, religious misconduct is not a popular subject in criminology. This situation, however, has two exceptions. The first one is that criminologists and historians published numerous studies on Islamic terrorism shortly after the September 11 Attack. Because of this intellectual movement, Islamic terrorism, to some extent, seems to have become synonymous with religion-related crime in modern criminology.

Besides Islamic terrorism, criminologists and sociologists have also published articles, books, and reports on Christianity-inspired crime. As a result of this scholarly attention, Christianity-stimulated crime (especially hate crime) appears to have grown into an alternative form of religious misconduct in the 2010s.

No matter whether the analysis on Islam-connected crimes is more popular than the research on Christianity-associated offenses, these two academic movements appear to serve as the core/foundation of current study on religious misconduct. With this in mind, the main ideas linked with these two movements will be discussed concisely in the following sections to show the status of present research on religion-related crime.

\section{THE STUDY OF ISLAM-RELATED CRIME}

When examining the situations under which Islam may operate as a "delinquent religion," researchers seem to focus their attention on two socio-religious factors-- one is gender inequality, the other is extremist Islamic beliefs.

The first factor is normally explored by those scholars specializing in gender study. According to these feminist writers, gender relationships of Islamic societies are, for the most part, arranged by Islamic commandments, especially the Sharia. Accordingly, innumerable females of Islamic societies experience the seemingly endless religious policing and institutionalized violence (e.g., the so-called honor killing) because Islamic societies per se are patriarchal establishments. In this regard, one representative example is offered by Brown's (2005) field study in Pakistan.

Unlike those writers who concentrate their research on the institutionalized gender violence of Islamic societies, some criminologists and criminal justice experts analyze the formation and development of Islamic terrorist movements. This research focus can be further divided into three dissimilar (but closely related) camps:

The first group is composed of those specialists who seek to understand the origins of the so-called "Holy War" (Esposito, 1999, 2002), "Cosmic War" (Juergensmeyer, 2000), or "Global Jihad" (Rashid,

\footnotetext{
${ }^{8}$ According to Wright (1986: 55 ), the pattern of "Holy War" can be a formal and large-scale warfare, a blockade (e.g., occupying the embassy of an "evil country"), or a campaign of underground terror.
} 
2000)-- e.g., why certain Muslims can be transformed by Islamic fatwas into fanatical terrorists ${ }^{9}$.

The second school includes those authors who try to identify the industries that provide the Islamic terrorist movements with resources. In this regard, some examine the role played by the drug business in financing the terrorist movements of the modern world (see Cooley, 2000:127-161; Rashid, 2000: 117-127); some investigate the connection between terrorist groups and smuggling (see Farah, 2004); while some explore those international financial markets and banking systems which allow Islamic terrorists to engage in money laundering and to obtain pecuniary support (see Adams, 1986; Schweitzer \& Schweitzer, 2002).

The third circle consists of those investigators who, by means of comparative research or case study, aim to show the diversity of Islamic terrorist organizations. According to these researchers, the Islamic terrorist movements of the modern world are not a campaign initiated/participated by extremist Muslims with the same behavioral patterns. Instead, these movements are composed of crusades launched and sustained by militant Muslims with different demographics, goals, and membership patterns (see Alexander, 2002; Gunaratna, 2003; Hoffman, 1998: 95-100; Valasik \& Phillips, 2017; Weiss \& Hassan, 2016).

\section{THE STUDY OF CHRISTIANITY-RELATED CRIME}

Like Islam-connected crime, the issue of Christianity-stimulated crime has been analyzed by scholars several times in the 2000s and 2010s. These analyses, taken as a whole, seem to center on the subject of Christianity as a stimulus for hate crime:

According to some writers (see Barkun, 1996; Quarles, 2004), the Bible, much like the Quran, can cause intense interpersonal conflicts because some messages of this Holy Book are manipulated into stories which promote racist and sexist beliefs. For example, the Christian Identity churches advocate the idea that only certain populations on Earth are God's chosen people. Accordingly, these individuals

\footnotetext{
${ }^{9}$ Matusitz (2014: 138) argues that Islamic beliefs can offer two ideological justifications to Islamic terrorists, namely exclusivism and chosen people. Exclusivism refers to a mentality that will make terrorists believe that they are the sole defenders of social justice and guardians of goodness in the modern world. Likewise, chosen people is a mentality or mindset. It will make terrorists feel that they are the agents of God (or Allah), that they are "divinely selected individuals," and that they have the "holy responsibility" of eradicating all "evil" and "immoral" populations.
}

particularly picked by God are entitled to govern the whole human race because their position is higher than others.

In terms of demographic feature, the Christian Identity churches, as well as those persons who firmly support White Nationalism/White Power, typically argue that only White people can be considered as God's children. This claim is mainly based on two pieces of "evidence":

First, according to disciples of the Christian Identity churches (as well as other hard-core racists of the same kind), the skin color of modern Caucasians is identical to that of Adam for the root meaning of the term Adam is "ruddy." That is, modern Whites and Adam share the same skin color because the skin of Caucasians is most likely to display reddish or pinkish pigment when compared to non-Whites (see Perry, 2001: 143).

In addition to skin color, the other "proof" frequently cited by members of White supremacist groups to show that White people are God's chosen people is that nonJewish Caucasians of the modern world are the offspring of the Ten Lost Tribes of Israel: ${ }^{10}$

For supporters of the Christian Identity (or Seedline) philosophy and adherents of the White Power Crusade (e.g., the Creativity Movement, see Michael, 2009), the Ten Lost Tribes of Israel were not really missing. On the contrary, these disappearing Tribes (probably as early as the Middle Age) had already migrated to West Europe and North Europe. Because of this "immigration history" (which might be little-known to the public), only non-Jewish people of the European descent can be regarded as the descendants of Jacob (i.e., God's chosen people).

In any event, the reasons stated above can provide hate groups and individual White racists with a "scientific foundation" in categorizing peoples. Since this classification is based on radical Christin beliefs (see Berry, 2017; Kaplan, 1993; Michael, 2009), hate crimes perpetrated by White Power followers naturally can be defined as a "necessary measure" that can help non-Jewish Whites preserve the "purity" of the White

\footnotetext{
${ }^{10}$ According to the Bible, ten of the twelve tribes of Israel became misplaced because of war (see Genesis, Exodus, Joshua, and $2 \mathrm{King}$ ). In this regard Bible researchers did propose some theories to explain the whereabouts of these ten lost tribes (see Brough, 2005: 37-91). These theories, however, will not be reviewed and compared in this article for it is beyond the scope of this paper.
} 
race and avoid "racial pollution" (see Bushart et al., 1998; Gerstenfeld, 2017; Gerstenfeld \& Grant, 2004; Hamm, 1994; Levin, 2007).

\section{AN ALTERNATIVE PARADIGM ON THE RESEARCH OF RELIGIOUSLY-INDUCED CRIME}

The arguments presented above clearly indicate that current study on religion-related crime has the weaknesses of incompleteness and imbalance. Expanding and elaborating extant research on religious misconduct is therefore critical and pressing for criminologists.

In terms of enriching existing study on religionrelated crime, this paper suggests that criminologists and criminal justice experts should pay more attention to criminogenic polytheistic beliefs (CPBs). If not, the study of religion-related crime may become synonymous with the examination of criminogenic monotheistic beliefs (CMBs).

Based on the claim that scholars did not pay enough attention to polytheistic beliefs when discussing the topic of religious misconduct, the following three subjects will be examined in the subsequent pages:

- $\quad$ First, the core features of polytheistic religions;

- Second, the principal characteristics of Chinese folk religion; and

- Third, the crimes supposedly originated from the Chinese folk religion.

The purpose of analyzing these issues is to show that besides monotheistic religions like Christianity and Islam, polytheistic religions can also serve as paradigms for students to inspect those criminal behaviors derived from religion.

\section{WHAT IS POLYTHEISTIC RELIGION: SOME MAIN FEATURES}

In terms of volume, innumerable world and local religions in the modern world involve the practice of worshipping deities. For that very reason, it is extremely difficult, if not impossible, to list all the gods and goddesses adored by Buddhists, Daoists, Hindus, and other believers of polytheistic religions.

While adherents of polytheistic religions (PTRs) display high level of heterogeneity in the objects of worship, PTRs tend to have five traits in common (see Armstrong, 1993, 2001; Kirsch, 2005; Reese, 1980: 7073, 222-225, 567-568). They are
- $\quad$ Lack of absolutist beliefs;

- Instrumental orientation;

- High level of inclusiveness;

- $\quad$ Pursuit of supernatural power; and

- Gender equality.

The first quality, shortage of absolutist beliefs, refers to the fact that polytheistic religions do not have a unified system of theology that can help followers establish a uniform (or homogeneous) religious life. As a result of this "freedom of faith," believers of polytheistic religions can worship different deities simultaneously and do not have to show total (or oneness) commitment to a certain god or goddess. In other words, disciples of polytheistic religions can worship all kinds of gods/goddesses, even these deities do not belong to the same religious sect or faith system.

Given that adherents of polytheistic religions can worship different deities at the same time, the faith of these believers is naturally instrument-oriented. That is, followers of PTRs usually will worship only those deities considered to be effective in helping people solve problems, no matter whether they are deified persons or sacred animals. In contrast, if deities are considered to be unproductive or unrewarding, then these divine beings usually will be disregarded by devotees of PTRs

The third trait of polytheistic religions, high level of inclusiveness, means that these belief systems will normally endorse or accept the concept that all religions will lead to the same outcome (i.e., all religions are the same in terms of helping people become charitable). As a result of this "open-minded thinking," members of polytheistic religions generally will not view each other as pagans as everybody will worship two or more deities ${ }^{11}$.

In addition to displaying high level of inclusiveness, another feature of polytheistic religions is that they can provide services to disciples ${ }^{12}$. That is, followers of polytheistic religions usually believe that the gods and

\footnotetext{
${ }^{11}$ For example, in Taiwan, not only can Buddhists of the North worship deities of the South (and vice versa); even worshiping foreign gods (when traveling overseas) is deemed reasonable by Taiwanese Buddhists.

${ }^{2}$ Obtaining these services is, needless to say, not free. On the contrary, people always have to offer money and/or gifts to a deity if they want to get assistance from this god or goddess.
} 
goddesses they worship possess supernatural power ${ }^{13}$. For that reason, believers of polytheistic religions will always expect the deities they adore perform "magic" for them, such as communicating with dead, cursing, fortune-telling, healing, matchmaking, practicing divination, and so forth ${ }^{14}$.

The final quality of polytheistic religions is that these faiths generally do not promote the thought of gender hierarchy (particularly the idea of patriarchy). PTRs therefore are rarely called a patriarchal belief (in this regard, PTRs clearly differ from Christianity and Islam).

After summarizing the major qualities shared by polytheistic religions, the central characteristics of Chinese folk religion (CFR) will be reviewed in the next part to show why and how the study of CFR-related crime can become a research paradigm as criminologists analyze those criminal/deviant behaviors stimulated by religion.

\section{CORE TRAITS OF THE CHINESE FOLK RELIGION}

According to Yang's (1991: 294), religions can be broadly divided into two categories. Some can be considered as an institutional religion because they possess the following three elements. In contrast, if a religion does not contain these three components, then it will be classified as a diffused religion.

an independent theology or cosmic interpretation of the universe and human events,

an independent form of worship consisting of symbols... and rituals, and (3) an independent organization of personnel to facilitate the interpretation of theological views and to pursue cultic worship (Yang, 1991: 294).

Based on this classification, the Chinese folk religion apparently is a diffused religion because its belief is a mixture of Buddhism, Daoism, and Hinduism (see next pages). In addition to being short of an independent theology, the Chinese folk religion has "no significant independent existence" (Yang, 1991: 295) for it is observable only in "ancestor worship," "the

\footnotetext{
${ }^{13}$ This belief (or anticipation) can be easily found among the Voodoo enthusiasts (see Rigaud, 2001).

${ }^{14}$ Since finding a "good religion" to solve various dilemmas in life is one of the main factors that will motivate people to join a polytheistic religion, PTRs naturally must prove that they are effective in helping people deal with difficult problems/situations. If not, a PTR may increasingly lose popularity and the ability to recruit new members-- whichever outcome occurs, a PTR always will lose financial support and face the crisis of marginalization.
}

worship of community deities," and "the ethicopolitical cults" (Yang, 1991: 295) ${ }^{15}$.

Given that the Chinese folk religion is a diffused religion, it is no surprise that it displays several distinct characteristics.

In the first place, adherents of the Chinese folk religion do not view Jehovah (or Allah) as the supreme God in the universe ${ }^{16}$. As an alternative, a certain god or goddess (e.g., Sakyamuni Buddha or Mazu) is considered to be the highest (or the greatest) Deity in the cosmos. That is, the Chinese folk religion is a highly flexible and personalized faith for people can worship whatever gods/goddesses (like the ones listed below) deemed to be "suitable" or "useful" (see Chamberlain, 2009):

- $\quad$ The first group is made up of heavenly emperors and empresses, such as Yuhuang dadi (jade emperor), Wangmu niannian (queen mother of the West), and Guangyin (goddess of mercy). They are normally worshiped by the public.

- The second set is composed of deified characters, such as distinguished teachers/philosophers/professionals, righteous officials, prominent military generals, and heroic figures in the Chinese (or Taiwanese) history. They are typically worshiped by specialists of a certain industry/occupation ${ }^{17}$.

- The third type involves guardian angels of vulnerable populations. They are commonly worshiped by those people engaging in dangerous or dirty jobs ${ }^{18}$.

- The fourth category covers homeless spirits (i.e., the spirits of those people who passed away in wars, natural disasters, or accidents). They are

\footnotetext{
${ }^{15}$ Although the Chinese folk religion is a diffused faith and does not have a "significant independent existence" like Christian churches (or Islamic mosques), the CFR is still a polytheistic religion. One important reason for this is that numerous Chinese in modern China, Hong Kong, Taiwan, Southeast Asia, and North America have a shrine for idols in their house. Because of this "customized design," innumerable Chinese can worship their ancestors community deities or engage in various religious activities (like burning joss paper for homeless specters during the Ghost Month) in their personal home.

${ }^{16}$ For believers of the Chinese folk religion, Jehovah, Jesus, and Allah are simply gods of the Western societies. These Western gods usually have nothing to do with the Chinese/Taiwanese society.

${ }^{17}$ For example, Hua Tuo (140-208 A.D.) usually is worshiped by medical staff; Confucius (551-479 B.C.) is typically adored by teachers; Bao Zheng (999 1062 A.D.) is generally idolized by judicial staff; while Yue Fei (1103-1142 A.D.) is normally admired by career soldiers.

${ }^{18}$ For instance, fishermen usually worship Mazu (goddess of sea); beggars generally worship Li Tieguai (Iron Crutch Li); while sex workers worship Zhu Bajie (Pigsy).
} 
chiefly adored by people during the period of Chinese Ghost Festivals.

- $\quad$ The fifth kind consists of those gods specializing in a certain field. They are mainly worshiped by people who have a special need related to that field ${ }^{19}$.

Simply speaking, disciples of the Chinese folk religion have many options before paying homage to a certain god/goddess, for there are so many deities and temples/shrines to choose from. For that very reason, not only can adherents of the Chinese folk religion worship the most important deity (i.e., master deity) in their life, they can also worship those "auxiliary deities" believed to be able to assist master deity. Besides letting followers enjoy "absolute freedom of faith," another important quality of the Chinese folk religion is that it does not require believers to behave according to divine rules of conduct stipulated by the Bible (or the Quran) or to read these Holy Books on a regular basis $^{20}$. As a result of this laxity, disciples of the CFR do not need to change their established lifestyle and ask forgiveness from God when praying to a deity ${ }^{21}$.

In brief, the Chinese folk religion is not as demanding as monotheistic religions because it allows adherents to worship several deities simultaneously ${ }^{22}$.

In addition to polytheistic worship, the CFR does not call for followers to confess that they are sinned. Neither will the CFR strictly require adherents to observe a certain set of rituals when worshiping a god or goddess.

Finally, the CFR does not ask believers to demonstrate total/oneness commitment. For that reason, followers can stop worshiping a god/goddess at any time if this deity is thought to be ineffective in helping people solve personal problems and/or enhance private wealth ${ }^{23}$.

\footnotetext{
${ }^{19}$ For example, unmarried persons can worship Yuexia Laoren (literally the old man under the Moon; i.e., god of matchmaking) if they want to find a spouse. Moreover, people can worship Caishen (god of wealth) if they have severe financial crisis.

${ }^{20}$ For disciples of the Chinese folk religion, these Holy Books are volumes written for the Westerners only. So these Books should be read by the Westerners and those Chinese who worship Jesus or Allah.

${ }^{21}$ Of course, believers of the Chinese folk religion still can voluntarily change their way of life if they feel that such transformation can help them enhance wisdom or gain a peaceful mind.

${ }^{22}$ These deities are, to an extent, changing for the "less competent" gods/goddesses will be increasingly replaced by the "more effective" ones.

${ }^{23}$ In a sharp contrast to this "soft stance" or "undemanding position," worshiping is by no means arbitrary for Christians and Muslims.
}

THE PRINCIPAL BELIEFS OF THE CHINESE FOLK RELIGION

After summarizing the primary characteristics of the Chinese folk religion, the fundamental beliefs of the CFR will be presented in this section.

As noted in the previous section, the Chinese folk religion is a diffused religion. The CFR therefore cannot provide disciples with a distinct and exclusive faith system for this religious sect does not have an independent theology.

While the CFR does not have a theology with a perspective of its own, the CFR still has its own theoretical frameworks and conceptual models on the cosmos and human affairs. These frameworks and models, which originated from Buddhism, Hinduism, and Chinese mythology, can be summarized into four major doctrines (see Jordan, 1981; Weller, 1994) ${ }^{24}$. They are polytheistic worldview, channeling, rebirth, and karma:

- Polytheistic worldview refers to the belief that there are numerous supernatural beings in the universe. These spirits can be divine beings or any deified persons/ancestors.

- Channeling suggests the idea that people can communicate with a god (or ghost), just like individuals can interact with one another. So if someone wants to get help from a deity, this person can express his/her wishes/needs to an immortal being through incense-burning, ouija board-playing, fortunate-telling, or spirit possessing.

- Rebirth denotes the faith that life is a circulation composed of previous, present, and future lives. In other words, people will be reborn over and over again if they cannot terminate or escape from the causal chains sown in the preceding life.

- Karma emphasizes the law that the good deeds committed by individuals in the previous life will

\footnotetext{
${ }^{24}$ Although these faiths can be found in both the Buddhist and Hindu literature, this does not imply that Buddhism, Hinduism, and the Chinese folk religion are all the same. In fact, these religions are different in core thought. In other words, Buddhism focuses on the issue of human sufferings; Hinduism concentrates on the subject of karma and reincarnation, while the Chinese folk religion centers on the problem of obtaining karmic reward (or wiping out karmic punishment). No matter whether these core ideas are compatible with monotheistic religions, it is clear that these beliefs per se are not criminogenic (for they are just religious theories about life and the universe). On the other hand, these religious ideas may become criminogenic if they are applied by religious villains to the real world in a misleading or highly distorted manner.
} 
allow people to enjoy good things in the present life. On the contrary, people will experience countless sufferings if they perpetrated many evil behaviors in the previous life ${ }^{25}$.

Although the CFR, to an extent, provided numerous Chinese with an irreplaceable spiritual sustenance in the past one hundred and fifty years, this religion can also function as a "bad religion" as well. This phenomenon appears to be closely related to the highly inclusive/flexible faith system of the Chinese folk religion.

\section{THE CHINESE FOLK RELIGION CAN BECOME A CRIMINOGENIC RELIGION: A TYPOLOGICAL ANALYSIS OF THE CRIMES BELIEVED TO BE DERIVED FROM THE DISTORTED FAITHS OF CHINESE FOLK RELIGION}

In the past one and half centuries, the Chinese folk religion attracted hundreds of millions of disciples in China, North America, Southeast Asia, Hong Kong, and Taiwan. Because of this "spiritual movement," the CFR undoubtedly can be considered as the mainstream religion of the Chinese (including Taiwanese) societies.

As indicated in the previous pages, the Chinese folk religion believes that the universe is governed by miscellaneous deities. For that reason, all religious sects affiliated with the CRF can worship a god or goddesses believed to be effective in helping people solve thorny problems. Besides displaying diversity in worship, another salient feature of the Chinese folk religion is that it advocates the concepts of karma and rebirth-- i.e., all human events can be attributed to karma, which can pass from one life cycle to the next; so if someone experiences a disaster for no reason at all, this misfortune must be caused by a bad karma of the previous life.

Allowing disciples to worship various deities and giving Buddhist/Daoist masters the authority to interpret human events from the perspective of karma are therefore the nucleus of the Chinese folk religion. These two elements, on the other hand, tend to form an opportunity structure for deviant Buddhist/Daoist teachers to commit crime (e.g., in the name of eliminating bad karma, sex offense can be disguised by religious hooligans as a "therapy" or "mending").

\footnotetext{
${ }^{25}$ That is, both honorable and stigmatized statuses do not remain forever. Instead, 'one's 'merit' (or 'demerit,' negative karma) gets gradually used up, and [people] need to be reincarnated to earn more merit or to escape the cycle of merit and demerit entirely..." (Smith \& Burr, 2015: 33).
}

In the following, the crimes (i.e., sex crime, crime of trust, and crimes of authority) allegedly caused by the distorted beliefs of the Chinese folk religion will be examined ${ }^{26}$

\section{SEX CRIME}

According to the Crime Classification Manual (Douglas et al., 1997), sex crime can take place in many contexts. One of them is religion.

In term of religious context, sex offense seems to be ubiquitous. For example, not only does child molestation exist among some Catholic churches (see Notes 3 and 6 above), this offense also occurs amid uncountable non-Catholic religious organizations. In this regard, two factors tend to play a key role in allowing certain Buddhist/Daoist masters to commit sex offense. One is charismatic authority, the other is the belief of karma/rebirth.

The first factor, charismatic authority, refers to the fact the Chinese folk religion is a polytheistic faith. Accordingly, almost all Buddhist/Daoist masters affiliated with the CFR will be deified by their adherents if these teachers demonstrate a unique wisdom/ability in helping people work out difficulties, communicating with the dead, and/or predicting the future ${ }^{27}$. So if immoral Buddhist/Daoist masters possess a deified identity, this reputation will help these religious criminals win the trust of followers. Such trust then provides corrupt Buddhist/Daoist teachers with

\footnotetext{
${ }^{26}$ Although sex crime, crime of trust, and crime of obedience are closely related to each other if they are committed in the context of religion, their surfacing generally will display a sequence of order. This sequential order tends to be strongly associated with Maslow's (2017) hierarchy of needs-- in the first place, the biological or physiological wants will motivate corrupt Buddhist/Daoist masters to commit sex crime. After the physical need has been satisfied, people will start to pursue middle-level needs like belonging or self-esteem This strongly implies that duplicitous Buddhist/Daoist teachers will (gradually) switch their attention from sexual pleasure to personal image for as long as these religious crooks can maintain good social image, this reputation will allow them to establish stable or strong bonds with supporters. Such connections will, in turn, provide degenerate Buddhist/Daoist teachers with opportunities to extort money from followers (e.g., investment fraud, which is a crime of trust). Finally immoral Buddhist/Daoist masters may, in one way or another, get involved in crime of obedience when they have become charismatic figures or spiritual leaders. This phenomenon, in Maslow's term, is caused by the need of self-actualization. In other words, when religious con artists have controlled followers, acquired stable income, and enjoyed high social status, these criminals will no longer permit any disciples to question their authority. So whenever these "grand masters" believe that their authority or position is declining or threatened, they may become involved in crime of obedience (e.g. abetting loyal disciples to intimidate those followers considered to be defiant) to protect or to verify their position (in contrast, hardly will crooked Buddhist/Daoist masters incite their disciples to commit genocide for this act always will bring disastrous outcomes to the former)

${ }^{27}$ Technically, the greater the extent to which Buddhist/Daoist masters (including delinquent ones) can gratify their adherents/admirers when performing these jobs, the higher the possibility that these teachers will be deified/worshiped.
} 
opportunities to access and manipulate disciples, especially female believers.

Demonstrating exceptional wisdom (or "supernatural power"), however, is a challenging job for religious charlatans because they cannot exhibit their charisma simply by presenting their standardized achievements like academic background. With this in mind, many unethical Buddhist/Daoist masters appeal to the explication of lun hui (i.e., transmigration, which includes the elements of karma and rebirth) to prove that they are sagacious and prescient.

As indicated, karma and rebirth are two of the leading precepts of the Chinese folk religion. According to these two concepts, human soul (which is immortal) will, once in a while, break away from an aging body (which is mortal) and resettle in a reborn body. As a result of this law, humans will experience two things after their physical body stops working. The first one, rebirth, refers to the phenomenon that deceased persons will recurrently return to the earthly world. This invisible movement, for the most part, involves the subsequent dynamic processes:

- In the first place, people will live somewhere on earth for a certain period of time after they were born.

- $\quad$ Then people will die.

- $\quad$ After people die, their physical bodies (which have become insensible and "useless") will be buried. Their spirits, however, still exist.

- So when the "right time" comes, the gone spirits will enter various new bodies and return to the Earth.

- $\quad$ After existing for another period of time, these bodies with returned souls will die again. For that reason, the departed spirits will be reborn and will get different bodies for another time.

Acquiring a new body, on the other hand, is not arbitrary or accidental. Instead, it is determined by someone's karmic status. That is, good karma accumulated in previous life will enable people to be born in an affluent society and/or well-to-do family in the next life. In contrast, people will be born in an impoverished society or family if their karmic status was low in the earlier life. Some people might even be born as those beasts that will be slaughtered for food if their karmic status was extremely low.
The concepts of rebirth and karma thus emphasize the "perfect linkage" between deeds and life experiences, especially bad karma and negative life experiences. Based on these ideas, some religious con artists associated with the Chinese folk religion told their female disciples that the dilemmas they are now facing arise from the bad karma of the earlier life ${ }^{28}$. Only having sexual intercourse with a Buddhist/Daosit master (i.e., religious con artist himself) can this evil causal chain be terminated. By the same token, only having sexual intercourse with religious con man himself can forthcoming troubles be circumvented ${ }^{29}$.

\section{CRIME OF TRUST}

For persons who are not adherents of the Chinese folk religion, the stories fabricated by religious con men may sound preposterous-- after all, modern scientists still cannot prove the actuality of Iun hui and the power of karma planted in the previous life.

Unlike people who do not accept the notion that human affairs are caused by good/bad karma, tens of millions of Chinese and Westerners firmly believe in lun hui-- for these individuals, almost all human events are related to karma because no one will suffer (or enjoy) something for no reason at all. Given that human affairs are, almost without exceptions, triggered by karma, the stories proposed by Buddhist/Daoist masters about suffering retribution for one's sins naturally should not be totally disregarded. Instead,

\footnotetext{
${ }^{28}$ One common method employed by fake Buddhist/Daoist masters in making their stories plausible is to present "eye-washing materials" (e.g., portrayals of Hellish sufferings) to their targets. Since these materials have strong visionary effects, they usually can enhance the validity and reliability for the concepts of karma and rebirth (in other words, the construction of lun hui usually involves visionary art for this painting seems to be the only channel that can help people understand the operation of spiritual world).

${ }^{29}$ One typical case was reported by the Apple Daily in April, 19, 2015. It involves a Taiwanese man, who claims that he is long wang ("dragon king") or shao zhu ("young lord") because he can help people alter their "bad destinies." More specifically, this man declares that he possesses magic power because he had once learned witchcraft in Thailand. Based on this self-proclaimed training and "supernatural power," this man opened a home shrine in his house as a "private clinic" (where services like fortune telling or marriage counseling will be provided). In addition to general services, this married man also offers two "special services" to young women. The first one is to provide the so-called "dragon energy" to young females-- according to this swindler (who will receive young women as disciples only), his "dragon energy" (i.e., sperm) can help people get rid of bad karma and obtain good luck. So if young women are bothered by thorny problems like chronic disease, financial crisis, or cheating, these females should sleep with him so that all bad karmas will be lifted (this service, on the other hand, is not free because "dragon energy" is a rare treasure; all young women therefore must make payments to "dragon king" if they want to be blessed by his "dragon energy"). Besides selling "dragon energy," this "young lord" also offers the service of spell-drawing to young females-- according to this con artist, he can draw spells that can help people stay away from potential disasters. So if young women want to get these magic spells, they must totally take off their clothes and let him draw the spells anywhere on their body. This service will, needless to say, allow this con man to make a pass at naked women while drawing. See Lian (2000) for more cases
} 
these accounts might help people identify the root cause of numerous unanticipated or bewildering events.

No matter whether lun hui truly exists, the faith of lun hui seems to provide religious con artists with an epistemological basis in deceiving followers and committing the crime of trust $^{30}$. In this respect, dishonest Buddhist/Daoist teachers can use several techniques to establish their authority and to win social trust (see http://fake-buddha.blogspot.com/2012/07/ blog-post_03.html, p.5):

- $\quad$ First, using social media to increase popularity;

- Second, founding "non-profit social relief foundations" to maintain popularity;

- $\quad$ Third, continually making public denotations and intermittently holding releasing-the-captiveanimal activities to create a philanthropic image;

- $\quad$ Fourth, repeatedly holding "religious services meetings" and inviting politicians to attend those gatherings to construct a revered identity; and

- $\quad$ Finally, openly displaying "miraculous pictures" in an exhibit area to make the public believe that a superman/superwoman has descended ${ }^{31}$.

After deceitful Buddhist/Daoist teachers have won social trust and attracted followers, they can start to preach the importance of offering sacrifices among disciples. That is, false-hearted Buddhist/Daoist masters can make their adherents believe that offering money and other material things to a Buddhist/Daoist teacher will help people eliminate ye zhang (i.e., destructive or detrimental seeds sown in the earlier life), gain wisdom, obtain a purified heart not disturbed by secular affairs, relieve psychological burdens, recover from a chronic or incurable disease, go to ji le shi jie (i.e., Land of Ultimate Bliss), and earn a

\footnotetext{
${ }^{30}$ In this paper, this crime is defined as the offense perpetrated by religious con artists for the purpose of swindling disciples out of their money. It can range from making adherents purchase worthless religious commodities to having believers buy luxury goods for their masters.

${ }^{31}$ In the 1990s, a Taiwanese man called Qi-li Song declared that he is the incarnation of God because he is omnipresent (i.e., he can appear in different places simultaneously). To make people believe that he can send his fen shen (literally split bodies) to any places he wants to go, he first publicly displayed many "supernatural photos" (which later proved to be just scissors-and-paste works) in an exhibition house. Then Song, probably by means of political donation, asked some politicians to give their endorsement to these pictures. As a result of these public exhibitions, Song was viewed by some persons as living God in Taiwan. This godly identity helped Song accumulate enormous wealth in the late 1990 s and early 2000 s.
}

respectable Buddhist title or rank (see http://fakebuddha.blogspot.com/2012/07/blog-post_03.html, p.4).

In contrast, if people refuse to present offerings to their masters, then this callous behavior will constitute a bad karma-- as mentioned, this evil element will be carried from this generation to the next. Because of this law, cold-hearted and apathetic persons will eventually suffer self-induced disasters in the future life ${ }^{32}$.

\section{CRIME OF OBEDIENCE}

As noted above, playing the role of Buddha (or any supreme beings) allows those religious con artists affiliated with the Chinese folk religion to acquire financial profits from disciples ${ }^{33}$. On the other hand, these religious charlatans will also inspire their adherents to commit crime of obedience. This situation usually involves the subsequent two scenarios: ${ }^{34}$

- First, in order to be treated as a "savior" or "deliverer," religious con-men, besides performing magic shows (see Note 31 above), always have to promote a special formula or therapeutic method.

- $\quad$ Since some religious charlatans claim that the special formula (or unique therapeutic method) he/she recommends can effectively cure a chronic disease (or even cancer), some people

\footnotetext{
${ }^{32}$ The Yun-gao Yi case can provide a textbook example in this regard. According to some reports (e.g., dailynews.sina.com/bg/chn/chnnews/ausdaily/ 20131010/21375053775.html; Phoenix Weekly, 2013, issue 28), Yi was merely a part-time artisan painter in Sichuan, China in the 1980s. In spite of the fact that he did not finish elementary education, $\mathrm{Yi}$ was packaged by two Taiwanese as a master of Eastern Art in the early 1990s. Since then, Yi was conferred several distinguished titles. First, Yi was portrayed as a grand master of Eastern Art. Then under the "verification" of scissors-and-paste pictures, he was promoted to be a master of Tibetan Tantrism and a fa wang (literally prince of Buddhist laws). Finally, Yi (because of his "achievements") was labeled as a living Buddha of Tibet in the late 1990s. After Yi was deified, many people in America, Hong Kong, and Taiwan decided to become Yi's disciples (for Yi was regarded as the only genuine living Buddha in the modern world). As a result of this widespread support, Yi claimed that he is the H.H. Dorje Chang Buddha III (which is the equivalent of supreme God for contemporary Buddhists) in 2008. So starting from 2008, Yi began to behave in ways as if he is a clairvoyant. All of these godlike behaviors not only allowed Yi to acquire enormous financial resources (e.g., in the name of offering sacrifices, Yi invited some of his wealthy disciples to donate millions of US dollars as his living expenses; Yi and his "Zen master" also obtained huge economic profits by selling inexpensive Buddhist paraphernalia to followers in high price), they also gave Yi the authority to launch a cult movement in the late 2000s/2010s (the Hua Zang Shrine of San Francisco seems to be the headquarter of this movement).

${ }^{33}$ In theory, the higher the degree to which religious con artists can win the trust from the masses, the greater the amount of pecuniary advantages these liars can get from their disciples.

${ }^{34}$ In this article, crime of obedience is defined as the illegal behavior committed by believers of the Chinese folk religion thanks to the teachings of religious con artists.
} 
unjustly died because they were forced to take counterfeit drugs or uncommon treatments ${ }^{35}$.

\section{CONCLUDING REMARKS}

In this paper, the issue of religious misconduct is examined. This theme, at least so far, appears to be a taboo subject in criminological research because extensively scrutinizing this what Lee (1993) called sensitive topic may harm the reputation of certain religious authorities (or even lead to the disintegration of certain religious organizations). Probably because of these concerns, crime researchers tend to view religious misconduct as merely a category of occupational crime(or crime of specialized access) when they analyze the dark side of religion.

In addition to the problem of underdevelopment, another characteristic of modern research on religious misconduct is that most researchers tend to focus their attention on monotheistic religion (particularly Islam and Christianity) only. As a result of this research orientation, religious misconduct is, more often than not, examined in the contexts of gender violence, hate crime, or terrorism.

This paper aims to extend/elaborate the research of religious misconduct. By using the Chinese folk religion as an example, the following points are suggested in this article:

First, polytheistic religions (e.g., the Chinese folk religion), just like monotheistic religions, can motivate people to commit property offenses or violent behaviors.

Polytheistic religions like the Chinese folk religion, however, seem to be less likely to motivate believers to commit violent behaviors (especially hate crime and terrorist acts). One important reason for this is that polytheistic religions do not include absolute faiths and do not require followers to show total commitment.

While the Chinese folk religion and other polytheistic religions tend to play a minor role in stimulating adherents to perpetrate hate crime and

\footnotetext{
${ }^{35}$ More specifically, some adherents of the Chinese folk religion have relatives who have cancers or chronic diseases. Instead of sending their sick relatives to hospital to get medical treatments, these believers may push their sick relatives to take the "special drugs" prescribed by religious con artists. Because of this irrational behavior, people compelled to take the "magic medicine" recommended by religious swindlers may sooner or later lose their life (otherwise, these persons may have had lived longer or even recovered from a disease if they had had received orthodox cures).
}

terrorist acts, the CFR can function as a criminogenic faith on many occasions. For example, some of the core doctrines of the CFR, such as rebirth and karma, can provide those religious con artists (particularly those who have already won social trust) with opportunities to fabricate stories and to mislead adherents. For that reason, false teachers affiliated with the Chinese folk religion can commit sex crime, crime of trust, and crime of obedience in the same fashion as traditional religious charlatans.

\section{REFERENCES}

Adams, J. (1986). The Financing of Terror: How the Groups That Are Terrorizing the World Get the Money To Do It. New York: Simon and Schuster

Alexander, Y. (2002). Palestinian Religious Terrorism: Hamas and Islamic Jihad. Ardsley: Transnational Publishers, Inc.

Armstrong, K. (2001). Buddha: A Penguin Life. New York: Viking Penguin.

(1993). A History of God: The 4000-Year Quest of Judaism, Christianity and Islam. New York: Alfred A. Knopf.

Barkun, M. (1996). Religion and the Racist Right: The Origins of the Christian Identity Movement, revised ed. Chapel Hill: University of North Carolina Press.

Berry, D. T. (2017). Blood and Faith: Christianity in American White Nationalism. Syracuse: Syracuse University Press. https://doi.org/10.2307/j.ctt1pk86c2

Brough, R. C. (2005). The Lost Tribes: History, Doctrine, Prophecies, and Theories about Israel's Lost Ten Tribes. Springville: Horizon Publishers.

Brown, L. (2005). The Dancing Girls of Lahore: Selling Love and Saving Dreams in Pakistan's Ancient Pleasure District. New York: Fourth Estate.

Bruni, F. and Burkett, E. (2002). A Gospel of Shame: Children, Sexual Abuse, and the Catholic Church. New York: Perennial.

Bushart, H. L., Craig, J. R., and Barnes, M. (1998). Soldiers of God: White Supremacists and Their Holy War for America. New York: Kensington Books.

Chamberlain, J. (2009). Chinese Gods: An Introduction to Chinese Folk Religion. Hong Kong: Blacksmith Books.

Cooke, T. (Ed.). (2011). Concise History of World Religions: An Illustrated Time Line. Washington D.C.: National Geographic.

Cooley, J. K. (2000). Unholy Wars: Afghanistan, America and International Terrorism, new ed. Sterling: Pluto Press.

Corbiscello, G. V. (2000). Ritualistic Crime and Investigation. N.A.: $1^{\text {st }}$ Books Library.

Douglas, J. E., Burgess, A. W., Burgess, A. G., and Ressler, R. K. (1997). Crime Classification Manual. San Francisco: JosseyBass Publishers.

Esposito, J. L. (1999). The Islamic Threat: Myth or Reality? 3e. New York: Oxford University Press.

Esposito, J. L. (2002). Unholy War: Terror in the Name of Islam. New York: Oxford University Press.

Farah, D. (2004). Blood from Stones: The Secret Financial Network of Terror. New York: Broadway Books.

Felson, M. and Boba, R. (2010). Crime and Everyday Life, 4e. Thousand Oaks: Sage Publications. https://doi.org/10.4135/9781483349299

Gerstenfeld, P. B. (2017). Hate Crimes: Causes, Controls, and Controversies, 4e. Thousand Oaks: Sage Publications. 
and Grant, D. R. (2004). Crimes of Hate: Selected Readings. Thousand Oaks: Sage Publications.

Green, G. (1996). Occupational Crime, 2e. Chicago: Nelson-Hall Publishers.

Gunaratna, R. (2003). Inside Al Qaeda: Global Network of Terror. New York: Berkley Books. https://doi.org/10.7312/guna12692

Hamm, M. S. (1994). American Skinheads: The Criminology and Control of Hate Crime. Westport: Praeger.

Hoffman, B. (1998). Inside Terrorism. New York: Columbia University Press.

Jenkins, P. (1996). Pedophiles and Priests: Anatomy of a Contemporary Crisis. New York: Oxford University Press.

Jordan, D. K. (1981). Gods, Ghosts, and Ancestors: The Folk Religion of a Taiwanese Village. Berkeley: University of California Press.

Juergensmeyer, M. (2000). Terror in the Mind of God: The Global Rise of Religious Violence. Berkeley/Los Angeles: University of California Press.

Kaplan, J. (1993). "The context of American millenarian revolutionary theology: The case of the 'identity Christian' church of Israel." Terrorism and Political Violence, 5 (1), 30-82. https://doi.org/10.1080/09546559308427196

Kirsch, J. (2005). God against Gods: The History of the War between Monotheism and Polytheism. New York: Penguin Books.

Kurst-Swanger, K. (2008). Worship and Sin: An Exploration of Religion-Related Crime in the United States. New York: Peter Lang Publishing.

Lee, R. M. (1993). Doing Research on Sensitive Topics. Newbury Park: Sage Publications.

Levin, J. (2007). The Violence of Hate: Confronting Racism, AntiSemitism, and Other Forms of Bigotry, 2e. Boston: Pearson Allyn and Bacon.

Lian, L. C. (2000). Shen Mi De Di Xiao Wang Guo: Jiao Men Hui Dao Men Yan Yi (Mysterious Kingdoms: A History of Chinese Secrets and Secret Societies). Fuzhou: Fujian People's Publishers.

Matusitz, J. (2014). Symbolism in Terrorism: Motivation, Communication, and Behavior. Lanham: Rowman \& Littlefield.

Maslow, A. H. (2017). A theory of Human Motivation. Lanham: Dancing Unicorn Books.

Michael, G. (2009). Theology of Hate: A History of the World Church of the Creator. Gainesville, University Press of Florida.

Parkinson, P. (2003). Child Sexual Abuse and the Churches: Understanding the Issues, 2e. Sidney: Aquila Press.
Perry, B. (2001). In the Name of Hate: Understanding Hate Crimes. New York: Routledge.

https://doi.org/10.4324/9780203905135

Quarles, C. L. (2004). Christian Identity: The Aryan American Bloodline Religion. Jefferson: McFarland \& Company, Inc., Publishers.

Rashid, A. (2000). Taliban: Militant Islam, Oil and Fundamentalism in Central Asia. New Haven: Yale University Press.

Reader, I. (2000). Religious Violence in Contemporary Japan: The Case of Aum Shinrikyō. Honolulu: University of Hawaii Press.

Reese, W. L. (1980). Dictionary of Philosophy and Religion: Eastern and Western Thought. Atlantic Highlands: Humanities Press.

Rigaud, M. (2001). Secrets of Voodoo. San Francisco, CA: City Lights Books.

Rosoff, S. M., Pontell, H. N., and Tillman R. H. (2002). Profit Without Honor: White-Collar Crime and the Looting of America, 2e. Upper Saddle River: Prentice Hall.

Schweitzer, G. E. and Schweitzer, C. D. (2002). A Fearless Enemy: The Origins of Modern Terrorism. Cambridge: Perseus Publishing.

Sells, M. A. (1996). The Bridge Betrayed: Religion and Genocide in Bosnia. Berkeley/Los Angeles: University of California Press.

Shoemaker, D. J. (2018). Juvenile Delinquency, 3e. Lanham: Rowman \& Littlefield.

Smith, H. (1991). The World's Religions: Our Great Wisdom Traditions. New York: HarperCollins Publishers.

Smith, D. H. and Burr, E. G. (2015). Understanding World Religions: A Road Map for Justice and Peace, 2e. Lanham: Rowman \& Littlefield.

Valasik, M. and Phillips, M. (2017). "Understanding modern terror and insurgency through the lens of street gangs: ISIS as a case study." Journal of Criminological Research, Policy and Practice, 3 (3), 192-207. https://doi.org/10.1108/JCRPP-07-2016-0014

Weiss, M. and Hassan, H. (2016). ISIS: Inside the Army of Terror 2e. New York: Regan Arts.

Weller, R. P. (1994). Resistance, Chaos and Control in China: Taiping Rebels, Taiwanese Ghosts and Tiananmen. Seattle: University of Washington Press. https://doi.org/10.1007/978-1-349-13203-4

Wright, R. (1986). Sacred Rage: The Wrath of Militant Islam. New York: Touchstone.

Yang, C. K. (1991). Religion in Chinese Society: A Study of Contemporary Social Functions of Religion and Some of their Historical Factors. Prospect Heights: Waveland Press, Inc.

\section{DOI: https://doi.org/10.6000/1929-4409.2019.08.07}

(C) 2019 Hua-Lun Huang; Licensee Lifescience Global.

This is an open access article licensed under the terms of the Creative Commons Attribution Non-Commercial License (http://creativecommons.org/licenses/by-nc/3.0/) which permits unrestricted, non-commercial use, distribution and reproduction in any medium, provided the work is properly cited. 